\title{
345 統合数值計算プラットフォームにおける
}

\author{
共通ファイルフォーマットを用いたプレポスト処理 \\ Pre- and Post-processing Using Common File Format \\ on An Integrated Numerical Simulation Platform
}

\author{
○正 河合浩志 (慶大理工) 正 野口裕久 (慶大理工) \\ Hiroshi KAWAI, Keio Univ. \\ Hirohisa NOGUCHI, Keio Univ.
}

Key Words: CAE, I/O, Pre-processing, Post-processing, Common File Format, Data Exchange, Integrated Numerical Simulation Platform

\section{1.はじめに}

近年、研究コミュニティおよびもの作りの現場にお いて、CAD/CAM/CAEあるいは CGやGIS 分野にお ける多くのアプリケーションパッケージが用いられる ようになって来ている。そして、これらのアプリケー ションと自分達で開発したプログラムとを互いに連 係させる必要が頻繁に生じている。このため、アプリ ケーションごとのデータファイルと、研究者自身が開 発するプログラムとのデータ交換が重要となる。し かしながら、多くの研究者にとって、こういったデー タ交換のためのファイル読み書きツールやコンバー 夕を開発することはきわめて面倒であり、また多く の時問を必要とする。

著者らは、複数のアプリケーションパッケージを利 用する研究活動を支援するための、統合数值計算プ ラットフォームを開発している ${ }^{(1)}$ 。本報告では、研 究者にとってシンプルで簡単に使えることを意図し たアプリケーション統合のための共通ファイルフォー マットを提案する。また、これを利用したアプリケー ション例として、有限要素法向けのプレポスト処理へ の応用を紹介する。

\section{2. 共通ファイルフォーマット}

現在著者らが開発中の統合数值計算プラットフォー ム ADVENTURE Auto (2) では、AutoCDM (AutoCommon Data with Meta-data)「おとしだま」と呼ば れる、メ夕共通ファイルフォーマットが定義されてい る(3)。また、このメタデータフォーマットを用いて、 いくつかの重要アプリケーション分野について、それ ぞれのアプリケーションドメインに特化した共通ファ イルフォーマットを定める作業が現在進行中である。 ここでは、有限要素アプリケーション分野への応用
について説明する。この有限要素解析およびプレポ スト処理向けの共通ファイルフォーマットは、C 言語 やFortranを用いる多くの研究者、エンジニアや学生 が比較的簡単にファイル読み込みや書き込みをする ことができるように設計されている。

AutoCDM で表現されるデー夕構造として、基本的 には、RDB(リレーショナルデータベース)に似たアプ ローチがとられている。それぞれの AutoCDM ファイ ルはひとつのテーブルである。テーブルは同一タイ プの複数のレコードより構成される。さらに、各レ コードは複数のフィールドより構成される。各レコー ドは同じ数のフィールドを有する。これらのレコード は順番付けされ、レコードIDがアサインされる。

図 1 に ASCII テキストフォーマットでの AutoCDM ファイルの例を示す。(a) は三次元での節点座標デー 夕、(b) は 4 節点四面体要素のコネクティビティデータ である。

以下に、AutoCDMに関するいくつかの特徵を述 ベる。

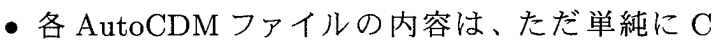
やFortranでの配列で表現することができる。 AutoCDM ファイルの先頭にはレコード数が記 されているため、プログラム内でのメモり管理 やアロケーションは楽である。

・ファイル読み書きプログラムの開発者は、AutoCDM ファイルを読み書きするのに、特別なラ イブラリを用いる必要がない。図1に示されて いるように、ほとんどのファイルはきわめてシ ンプルである。

•または、ADVENTURE Auto の AutoRESource ライブラリを用いて AutoCDM ファイルを読み 書きすることもできる。

[No.06-9] 日本機械学会第 19 回計算力学講演会講演論文集〔2006-11.3 5 - 名古屋市 $]$ 


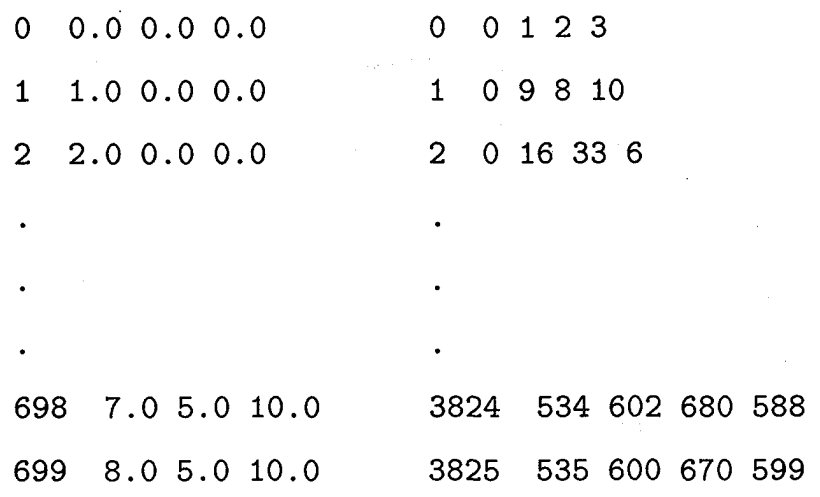

(a) nodal coordinate (b) element connectivity

図1 Example AutoCDM files (ASCII text version)

・データチェックやASCII テキスト・バイナリ変 換など、ファイルに関するさまざまな作業を自 動化するために、AutoCDMに基づくメタデー 夕を利用することができる。

\section{3. 適用例}

共通ファイルフォーマットAutoCDM 形式の実用性 を評価するため、有限要素解析向けプレポスト処理 ライブラリAutoMESHのファイル入出力にこれを用 いた。

AutoMESH「おためし」(4) は、メッシュの生成や 加工、メッシュ上の物理量操作および可視化などを行 うためのツールキットであり、多数のコマンドからな る。二次元問題での三角形要素、および三次元問題で の三角形シェル要素、四面体ソリッド要素に対応して いる。以下に、ここで用いられたファイルフォーマッ トの種類を列挙する。

- 形状データ

- 形状頂点座標

- 形状稯線

- 形状表面

- 形状三角形パッチ

- 形状輪郭線

・メッシュデータ

- 節点座標 (二次元と三次元)

- 要素コネクティビティ(各種要素タイプご とに)

・メッシュからの派生データ

- メッシュ内の全要素稜線
- 要素から要素稜線への参照

- メッシュ内の全要素表面

- 要素から要素表面への参照

- 要素隣接関係

'— メッシュ境界上の要素表面 (表面パッチ)

・物理量データ

一 節点上のスカラー量 (初期条件および解析 結果)

一 節点上のベクトル量 (初期条件および解析 結果)

- スカラー量の境界条件

- ベクトル量の境界条件

- 可視化データ

ー メッシュ輪郭線

一 等高線形状

- 断面形状

- 断面上サンプル点群と要素内補間データ

- 等值面形状

- ストリームライン軌跡形状

\section{4. おわりに}

アプリケーション統合のために、統合数值計算プ ラットフォーム、ADVENTURE Autoを開発した。ア プリケーション分野ごとの共通ファイルフォーマット AutoCDM、および、ファイルコンバータモジュール Auto2DAIを用意した。これらは、研究者やエンジニ アが自身で開発するプログラムと外部アプリケーショ ンパッケージとの間でデー夕を交換するために役立て ることができる。また、この共通ファイルフォーマッ トAutoCDMを用いた応用事例として、プレポストラ イブラリAutoMESHを紹介した。

なお本研究では、文部科学省 21 世紀 COE プログ ラム「知能化から生命化へのシステムデザイン」よ り御支援を得た。

\section{参考文献}

(1) 河合·野口、計算力学講演会論文集、17(2004),569570.

（2）河合-吉村、日本計算工学会論文集、7(2002),207210.

(3) 河合·野口、日本計算工学会論文集、11(2006),???.

(4) 河合・吉村、日本計算工学会論文集、9(2004),859862. 